http://revped.ise.ro

Print ISSN 0034-8678; Online ISSN: 2559 - 639X

\title{
PROCESS CONSULTATION FOR QUALITY ASSURANCE IN SCHOOLS IN VRANCEA COUNTY
}

CONSULTANȚA DE PROCESS PENTRU ASIGURAREA CALITĂȚII ÎN ȘCOLI ÎN JUDETTUL VRANCEA

\section{Paul BLENDEA, Irina GEANĂ}

\author{
Journal of Pedagogy, 2018 (2), 179 - 187 \\ https://doi.org/10.26755/RevPed/2018.2/179
}

The online version of this article can be found at: http://revped.ise.ro/category/2018-en/

\section{(C) 100}

This work is licensed under the Creative Commons Attribution-NonCommercial-ShareAlike 4.0 International License.

To view a copy of this license, visit http://creativecommons.org/licenses/by-nc-sa/4.0/ or send a letter to Creative Commons, PO Box 1866, Mountain View, CA 94042, USA.

Published by:

\section{INSTITUTUL DE ȘTIINȚE ALE EDUCAȚIEI}

http://www.ise.ro/

Further information about Revista de Pedagogie - Journal of Pedagogy can be found at:

Editorial Policy: http://revped.ise.ro/editorial-policy/

Author Guidelines: http://revped.ise.ro/the-writer-guide-2/ 


\title{
PROCESS CONSULTATION FOR QUALITY ASSURANCE IN SCHOOLS IN VRANCEA COUNTY
}

\author{
Institute of Educational Sciences \\ Bucharest, Romania \\ pblendea@ise.ro \\ irina.geana@ise.ro
}

\section{Paul Blendea* Irina Geană ${ }^{* *}$}

\begin{abstract}
The training program "Process Consultation - an Intervention Model" is conceptually covered by the existing management and quality assurance system in Romania, starting from the premise that any activity carried out in school should have as aim to improve quality, reflected in pupils through good and very good results, "wellbeing" and the progress they have made.

The purpose of this program was to give access to certain information necessary in day to day activity and also to bring consciousness to those involved in managerial tasks in school. 100 school principals from Vrancea County were trainees in the consultation process with a long term aim: improving the quality of learning and teaching in school.
\end{abstract}

Keywords: Management, process consultation, quality, school principal, training.

\section{Rezumat}

Programul de formare „Consultan a de proces - un model de interven ie” se incadrează, din punct de vedere conceptual, în sistemul existent de management şi de asigurare a calită ii din România, care porneşte de la premisa că orice activitate derulată în şcoală trebuie să aibă ca scop îmbunătă irea calită ii,

\footnotetext{
* Researcher, Institute of Educational Sciences, Bucharest, Romania.

** Research assistant, Institute of Educational Sciences, Bucharest, Romania.
} 
reflectată la nivelul elevilor prin rezultate bune şi foarte bune, „stare de bine” şi prin progresul înregistrat de aceştia.

Cuvinte cheie: Calitate, consultan a de proces, director de şcoală, formare, management.

\section{Introduction}

The "Process Consultation - an Intervention Model" training program developed by researchers from the Institute of Educational Sciences (IES) was initiated on the basis of the strategic guidelines launched by the Romanian Ministry Education (RMERS, 2014b) and the gaps identified by the IES (Iosifescu 2000; Iosifescu 2001; Mihail 2001) in initial management training.

Being a school principal is a profession in itself not an occupation, even if, legally, the standards in force refer to the occupation of a principal. Regardless of the type and level of the school, the profession and the professionalism as a manager meet certain requirements and are subject to some principles. This professionalism responds to the pressure of the specialized response, especially in special situations (crises, disruption of the working agenda, negotiation, etc.), and the investment range of the individual (training courses, masters, other legal requirements) requires another social status. Professionalize the school principal, seen as a vocational path, is not just a thought, but a stringent requirement to improve the quality of pre-university education - one cannot ensure the quality of education in a school and in public or private national system if one do not have selection criteria. Once these exist, it results implicitly that some have personal qualities to be a good principal, and others do not. A teacher, however well trained in the field of educational management, having a Master degree or other educational management studies, may not have the necessary skills to be a good school principal.

What we wanted to achieve through this program was to give managers, board members, Department heads and teaching staff aspiring to leading positions access to management consulting and to increase the number of those concerned with their own profession as conscious owners of the skills they can develop in the idea of adding value. 
The objectives of the program were as follows:

- The initiation in the process consultancy of 100 school principals, members of the School Board and teaching staff aspiring to leading positions in Vrancea County through 43 training hours, of which 34 hours were done on the noultraining.ise.ro platform, 3 hours of general legal notions, 3 hours of basic principles and basic legislation and 3 hours of evaluation;

- Develop the skills of the trainees in solving the school problems, by elaborating the School Improvement Plan (SIP) and solving a stringent problem of the schools where they work;

- Acquiring the basic notions of the Romanian legal system through 3 hours of legal notions;

- Developing the abilities of law enforcement officers related to the legislation specific to the education system, through 3 hours of training on fundamental principles and basic legislation.

The staff targeted by this training program consisted of 100 school principals, School Board members and teaching staff aspiring to leading positions in Vrancea County, and the subjects and themes they went through can be seen in Table no. 1.

Table no. 1. Subjects and topics covered

\begin{tabular}{|l|l|l|}
\hline No. & \multicolumn{1}{|c|}{ Topics } & \multicolumn{1}{c|}{ Themes } \\
\hline 1. & Process consultation & $\begin{array}{l}\text { Group rules, enrolment and ways to use the noultraining.ise.ro } \\
\text { platform, the definition of process consultancy, the role of the } \\
\text { process consultant and the client organization. }\end{array}$ \\
& \multicolumn{1}{|c|}{$\begin{array}{l}\text { Facilitations, applications, consultancy, evaluation. } \\
\text { Customer actions, diagnosis and intervention. } \\
\text { Process consultation in E. Schein's vision. }\end{array}$} \\
\hline 2. & General legal notions & $\begin{array}{l}\text { Fundamental principles and basic legislation in the Romanian } \\
\text { educational system. }\end{array}$ \\
\hline
\end{tabular}

Under the program, trainees have acquired a range of managerial and legal skills that can be seen in Table no. 2 . 
Table no. 2. General competences acquired

\begin{tabular}{|l|l|}
\hline No & \multicolumn{1}{|c|}{ Competence } \\
\hline 1. & Communication with school groups and staff \\
\hline 2. & Using on-line platform noultraning.ise.ro \\
\hline 3. & Facilitating group activity and process consultation \\
\hline 4. & Diagnosis, intervention and problem solving \\
\hline 5. & Knowledge of the basic notions of the Romanian legal system \\
\hline 6. & Applying the legal norms related to the legislation specific to the education system \\
\hline
\end{tabular}

\section{Indicators for Program Implementations}

In Educational Management planning, one of the things that researchers have to work out is a set of indicators that will be used to measure outputs against program goals. We choused some appropriate quantitative and qualitative performance indicators starting from a set relevant questions about the scope, objectives an outcomes of the program.

Table no. 3. Performance indicators

\begin{tabular}{|l|l|l|l|l|l|l|l|}
\hline $\begin{array}{c}\text { Quantitative } \\
\text { performance } \\
\text { indicators }\end{array}$ & Proposed & Achieved & $\begin{array}{c}\text { Percentage } \\
\%\end{array}$ & $\begin{array}{l}\text { Qualitative } \\
\text { Performance } \\
\text { Indicators }\end{array}$ & Proposed & Achieved & $\begin{array}{c}\text { Percentage } \\
\%\end{array}$ \\
\hline $\begin{array}{l}\text { Number of } \\
\text { trainees } \\
\text { enrolled }\end{array}$ & 100 & 100 & $100 \%$ & $\begin{array}{l}\text { Number of } \\
\text { students' } \\
\text { complaints }\end{array}$ & 0 & 0 & $100 \%$ \\
\hline $\begin{array}{l}\text { Graduation } \\
\text { rate }\end{array}$ & 100 & 100 & $100 \%$ & Drop out & 0 & 0 & $100 \%$ \\
\hline Attendance & $75 \%$ & $75 \%$ & $100 \%$ & Publications & 1 & 1 & $100 \%$ \\
\hline $\begin{array}{l}\text { Number of } \\
\text { inputs on } e \\
\text { learning } \\
\text { platform }\end{array}$ & 400 & 244 & & $\begin{array}{l}\text { Debates, } \\
\text { seminars and } \\
\text { round tables }\end{array}$ & 1 & 1 & $100 \%$ \\
\hline & & & $\begin{array}{l}\text { A thank-you } \\
\text { letter from the } \\
\text { partner }\end{array}$ & 1 & 1 & $100 \%$ \\
\hline & & $\begin{array}{l}\text { Starting new } \\
\text { projects with } \\
\text { the same } \\
\text { partner }\end{array}$ & 1 & 1 & $100 \%$ \\
\hline
\end{tabular}




\section{Process Consultation - An Intervention Model}

Every organization has a purpose and a mission, and the consultant is primarily interested in their formulation and the means used. These goals are communicated and internalized by members of the organization, and the consultant is interested in the forms of communication used and how members relate to each other, individually or in groups. Problem-solving processes require the involvement of leaders who use various leadership methods and techniques. Meetings take place, decision-making processes are taking place and decisions are made.

Pre-university education managers need in their work conceptual models that synthesize the activity of the consultant or facilitator to start the study of human processes, the interaction between the organization and the external environment, the results obtained and the techniques of their observation, the dynamic dynamics of success - failure. Such a conceptual model is presented in the works of Edgar Schein, the founder of the Process Consultation field, on the basis of which these materials are developed for the course (Schein1988). Process Consultation is a set of activities done by the consultant that helps the customer to perceive, understand and act on the processes that occur in the client organization in order to improve the customer-defined situation. The process consultant assists in gathering the data, but the client organization or manager needs to collaborate in formulating the diagnosis and they will decide when this data is sufficient. The consultant will avoid making premature diagnoses.

Several models of observation, diagnosis and intervention, specific to process consultation were presented in the course materials. The phenomena that a consultant can see and where they can intervene can be: face-to-face relationships between two or more people, and group and inter-group situations. Face to face relationships can be polarized relationships: respect lack of respect, collegiality - animosity, formalism - proximity. Group and inter-group situations include: the existence of subgroups in the organization that may or may not coincide with functional subdivisions; relations between them: tensions - cooperation, power games and struggle for power, circulation of information, participation in the decision; norms, organizational culture, leadership, here one can analyse the explicit rules and implicit rules, the 
distance to power (strict hierarchical relations or horizontal cooperation), the characteristics of leadership. The process consultant assists in gathering the data, but the client organization or manager needs to collaborate in formulating the diagnosis and they will decide when this data is sufficient.

Diagnosis and intervention are activities through which the facilitator intervenes in the organization through questions, application of tools, discussions with members of the organization, organization of activities, training and counselling. They cannot be separated from the point of view of the intervention even if these actions are conceptually separated. The organization features both static and dynamic elements, stabilizing its own culture and structure. The structural approach is a great temptation because we are accustomed to thinking in these terms, and often we come to false definitions of problems and false perceptions of reality. It is often proposed to change the organizational chart / staff structure, establishment / abolition of posts; individuals and their personality can be treated statically, as structural factors, not as subjects of change.

\section{School Improvement Plan (SIP)}

The SIP was proposed within the program as a facultative activity, and it remains at the discretion of the school management how it will be introduced either as part of the Institutional Development Plan (IDP) or as a standalone plan.

The purpose of SIP is to improve the quality of teaching and learning in school so that more and more students have good results in Romanian, mathematics and science. The school will have to develop a two-year plan that focuses on the core disciplines where weaker results have been achieved. It is advisable for the school to develop the plan within two to three months of identifying the problems.

SIP contains a number of elements, including: strategies based on scientific research; policies and practices that will make all pupils achieve at least satisfactory results in fundamental subjects; the setting of specific, measurable objectives and a one-year deadline for the continuous progress of pupils; to specify the responsibilities for school and educational partners in implementing 
the plan; to include strategies that will promote the effective involvement of parents in school activities; to include learning activities before the start of classes, after they are completed and during holidays; to incorporate strategies that promote the professional development of teaching staff (Pinellas County Schools, 2016).

Here are some examples of policies and practices that could be used in schools included in the program: massive introduction of active-participatory work methods; regular analysis of learning outcomes and other data; involving teachers and parents in decision-making and the correct allocation of resources to support fundamental goals; choosing training programs and teaching materials; effective use at times of time; improving how the results of the evaluations are used.

SIP should take into account the professional development of leadership and teaching staff, because student success is closely linked to teacher training and skills. Professional development is crucial to ensure continuous improvement in working skills with pupils to help them achieve at least satisfactory results in evaluations. The professional development that should be provided will focus on the teaching and learning process. For example: using active-participatory methods, initiating students into new learning methods; teacher training in analysing data on the class and school situation, and then using this analysis in classroom activity.

Parents could be included in the SIP as follows: each parent will be informed in writing that the school has identified the need to implement such a document; SIP specified the strategies that were used to promote parent involvement; effective strategies are those involving parents as teachers' partners in educating children and making decisions in school.

SIP contains measurable goals, the plan has goals correlated with the desired results. Goals provide a means of tracking school progress over the two years during which the plan is being implemented. During the elaboration / revision of the SIP, the school will consult with: parents, teaching staff, inspectors from the County School Inspectorate, experts from the Institute of Educational Sciences and from the Romanian Agency for Accreditation of Quality in Pre-university Education (RAAQPE). 
The process of reviewing SIP could follow as follows: two independent evaluators give a verdict on the viability of the plan within 30-45 days of receiving it. The County School Inspectorate (CSI) should involve teachers and school managers with the same profile as evaluators, but whose students have achieved much better results.

\section{Conclusions}

The main conclusions of the implementation of the "Process Consultation an Intervention Model" program areas are the following:

- There is a demand for training, but the Ministry of Education has not taken effective action to create a market for training and financing of training;

- Trainees are poorly motivated to participate in training because the training they attend is not rewarded by substantial wage increases;

- School principals are overloaded and should be relieved of classroom hours.

\section{References}

- Blendea, P., \& Măntălu ă, O. (2014). Consiliere şi consultan ă managerială pentru personalul de conducere al unită ilor de învă ământ preuniversitar. Revista de pedagogie, 1, 161-170.

- Blendea, P., \& Măntălu ă, O. (2015). Program de mentorat pentru directorii de unită i de învă ământ preuniversitar. Revista de pedagogie, 2, 107-114.

- Blendea, P., Măntălu ă, O., Catană, L., Căpi ă, L., Voinea, L., \& Teşileanu, A. (2015-2016). Instrumente şi metode pentru îmbunătă irea func ionării Consiliului de Administra ie din unită ile de învă ământ preuniversitar. Institute of Educational Sciences.

- Blendea, P., Măntălu ă, O., Mihail, T.M., \& Pop, V. (2011). Planul de Dezvoltare Institu ională $(P D I)$ - un instrument al schimbării. Institute of Educational Sciences.

- Hanover Research. (2014, October). Best Practices for School Improvement Planning. Retrieved from http://www.hanoverresearch.com/media/BestPractices-for-School-Improvement-Planning.pdf. (accessed on 12 October 2016).

- Iosifescu, Ş. (Coord). (2000). Manual de management educa ional pentru directorii de unită $i$ şcolare. Institute of Educational Sciences, ProGnosis Publishing House. 
- Iosifescu, Ş. (Coord). (2001). Management educa ional pentru institu iile de învă ământ. Institute of Educational Sciences, Tipogrup press Buzău.

- Măntălu ă, O., Blendea, P., Fartuşnic, C., Iacob. M. \& Mihail, T.M. (2012). Dezvoltarea profesională a personalului de conducere al unită ilor şcolare de nivel preuniversitar printr-un program complex de consiliere şi asisten $\breve{a}$ in mediu online. Institute of Educational Sciences.

- Mihail, T. M. (ed.). (2001). Ghid metodologic pentru formarea formatorilor management educa ional. Institute of Educational Sciences, Tipogrup press Buzău.

- Pinellas County Schools. (2016). School Improvement Plans. Retreived from http://pcsb.org/Page/21555. (accessed on 19 October 2016).

- Romanian Government. (2008). Strategia Na ională pentru Dezvoltare Durabilă a României Orizonturi 2013-2020-2030. Bucharest.

- Romanian Ministry of Education, Research and Science. (2014a). Ordin $n r$. 4619/2014 pentru aprobarea Metodologiei-cadru de organizare şi func ionare a consiliului de administra ie din unită ile de învă ământ preuniversitar. Bucharest.

- Romanian Ministry of Education, Research and Science. (2014b). Strategia pentru învă area pe tot parcursul vie ii 2015-2020. Bucharest.

- Schein, E. H. (1988). Process consultation: Volume I: Its role in organization development. 2nd Ed. Reading, MA: Addison/Wellesley Publishing Company.

The online version of this article can be found at: http://revped.ise.ro/category/2018-en/

\section{(cC) BY-NC-sA}

This work is licensed under the Creative Commons Attribution-NonCommercial-ShareAlike 4.0 International License.

To view a copy of this license, visithttp://creativecommons.org/licenses/by-ncsa/4.0/ or send a letter to Creative Commons, PO Box 1866, Mountain View, CA 94042, USA.
Versiunea online a acestui articol poate fi găsită la:http://revped.ise.ro/category/2018-ro/

\section{$(c c))$ BY-Ne-zA}

Această lucrare este licen iată sub Creative Commons Attribution-NonCommercial-ShareAlike 4.0 International License.

Pentru a vedea o copie a acestei licen e, vizita $i$ http://creativecommons.org/licenses/by-nc-sa/4.0/ sau trimite i o scrisoare către Creative Commons, PO Box 1866, Mountain View, CA 94042, SUA. 